This is a postprint version of:

González Ramos, A. M., \& Vergés Bosch, N. (2013). International mobility of women in science and technology careers: shaping plans for personal and professional purposes. Gender, Place \& Culture, 20(5), 613-629.

\title{
International mobility of women in science and technology careers: shaping plans for personal and professional purposes
}

\author{
Ana M. González Ramos \\ IN3. Universitat Oberta de Catalunya
}

\author{
Núria Vergés Bosch \\ Universitat de Barcelona
}

\begin{abstract}
International mobility has become a key requirement in science and technology (S\&T) professional career progression. On the one hand, the increasing mobility of women suggests that this may be a way for them to avoid or get away from women-unfriendly working environments. On the other hand, international mobility can present problems for women as they, particularly, have to plan their lives around their professional goals and personal lives. This article addresses the international mobility strategies of women regarding their personal and professional choices. We analyse their motivations to move, the way they manage their lives abroad and the effects of mobility on their lives. The analysis is based on 24 in-depth interviews of highly skilled women working in Spanish S\&T sectors. Our main findings show that mobility is a new challenge which may improve women's family lives and professional careers. However, they have to plan carefully their lives on a long-term as well as a daily basis. In this sense, they need strong personal determination and the ability to balance their professional and personal goals. Moreover, their personal decisions depend not only on them as individuals, but also on their partners and families, on wider social values, on the institutional support they enjoy, and on the general public policies which they are affected by.
\end{abstract}

Keywords: career advancement; highly skilled personnel; mobility; gender; personal relationship; work- life balance

\section{Introduction}

International mobility, or the movement across national boundaries of highly skilled personnel for training and work purposes, has recently increased as a result of the internationalisation of the science and technology (S\&T) sector. There are several explanations for this increase: the globalisation of the labour market; the promotion of organisational mobility strategies to support the recruitment of talent from around the world; the competitive strategies of S\&T institutions based on the attraction of excellent professionals; and the strong motivation of highly skilled people to learn and train in international institutions (Castells 1996; Koser and Salt 1998; Mahroum 2000, 2001; OECD 2001; Solimano 2008). All these issues are related to the growth of an economy based on knowledge, and to increasing competition for high-quality human resources in $\mathrm{S} \& \mathrm{~T}$.

Highly skilled personnel move from one country to another motivated by both voluntary and mandatory reasons (Mahroum 2000; Solimano 2008). On the one hand, mobility gives young scientists essential professional experience and personal enrichment. These young scientists stress their enjoyment of their time abroad more than the language 
and knowledge they acquire (King and Ruiz-Gelices 2003). On the other hand, certain countries, such as Spain, require researchers to go abroad to progress in their scientific careers. Foreign work experience is a requirement for holding a permanent position in academia (according to the Spanish Agency of Assessment of Research Activity, ANECA). Large and multinational S\&T companies include international assignments for their workers within their corporate strategies (Koser and Salt 1997; OECD 2001). In general terms, then, the mobility of senior researchers and highly skilled staff strengthens their international networks and their professional profile, and consolidates their position among their peers (Laudel 2005; Jöns 2007). Professional and personal motivations come together, for instance, when professionals from less developed countries decide to take jobs in developed economies (Solimano 2008).

International mobility represents a challenge for all highly skilled people, but it has to be examined from a gender perspective. In the first place, we need to understand whether or not women develop their international careers to the same extent as men. Second, we need to know how women manage international mobility. Finally, we need to consider the extent to which international mobility affects their professional and personal lives. Mobility which takes place in the early stages of their professional careers occurs simultaneously with the establishment of partnerships and adult life planning. The potential for international mobility is therefore influenced by personal issues such as the attitudes of partners and even the opinions of close relatives. In addition, if women are mothers, they need to take into account how they will support their children abroad, considering the opportunities for work- life balance, the ability to access public and private support services, and the overall gendered culture of the country they are considering moving to. This article explores how women develop their international careers while also managing their professional and personal issues. We are interested in exploring the main episodes of their lives in relation to mobility, the moment when they decide to go abroad (or return), as well as the main events in their careers and personal lives. We address their discourses and the arguments they deploy to explain their decisions. We explore their mobility strategies regarding their professional careers, partnerships, motherhood and family relationships, their recollections of events that have happened in their lives and the meanings these have had for them. Any type of mobility (short-term or longterm) shapes the life-course and the daily life of professional women. As Hanson (2010) points out, any kind of mobility affects the private lives of women and, conversely, their private circumstances also modify their mobility strategies. Other factors such as their country of birth, socio-economic position, family commitments and professional orientation also need to be taken into account to fully understand their decisions and their lives abroad.

In what follows, we set out the mobility strategies of women involved in S\&T professions in Spain. In the first section, we address international mobility from a gender perspective, presenting the main debates in the literature. In the second section, we detail our study methodology and the features of the women interviewed. In the subsequent sections, we present our results which are divided into two sections, reflecting women's long-term career strategy planning and their daily work- life balance arrangements. Within this discussion, first, we address their reasons for moving, and the personal and professional influences on their mobility strategies; second, we discuss the ways in which they tackle their daily professional and personal lives abroad. Both issues are related to their families, the public policies in their home and host countries, and to other institutional factors. Finally, we try to shed light on our main findings and propose new actions to support the international mobility of women. 


\section{Mobility in S\&T from a gender perspective}

According to the Canberra guidelines (OECD 1994), highly skilled personnel are defined as people with higher qualifications (preferably, to tertiary education level), or professionals and technicians working in S\&T occupations. In a broad sense, S\&T activities are related to scientific and engineering fields of knowledge that are commonly carried out in particular institutions. Our study aims to explore women's lives as they develop their professional careers in universities, public institutions and enterprises specialising in research and innovation. As we have already stated, this sector has been strongly affected by an internationalisation of work, and therefore it constitutes a fruitful area for mobility research.

The growing international flows of women indicate that the globalisation of the S\&T labour market creates significant opportunities for highly skilled women. Comparisons between men and women show that women are more likely to move between OECD countries when they have high educational qualifications (Dumont, Martin, and Spielvogel 2007; Docquier, Lowell, and Marfouk 2009). On average, the mobility rate of tertiarylevel educated women is $17.6 \%$ compared to $13.1 \%$ for men, and the differences between female and male rates are greater in less developed economies: in Africa women's mobility rates are $27.7 \%$ compared to $17.1 \%$ for men; in Latin America women's mobility rates are $21.1 \%$ compared to $17.9 \%$ for men. A small gender gap is found in Asia and Oceania, while there is no gap in Europe and North America (Dumont, Martin, and Spielvogel 2007; OECD 2007, 2008). These figures suggest that women are positively affected by both the dynamics of the global labour market and their greater skills in S\&T areas.

The increasing movement of highly skilled women has increased academic interest in, and research about, women's international mobility. A key dimension of academic analysis examines the role of women in mobility strategies, and compares women's and men's longterm professional advancement (Xie 2010). It also explores the obstacles to progress in professional careers, arguing that international mobility is primarily centred on male working patterns. According to this argument, women are potentially affected by mobility because they can lose their jobs, abandon their professional aspirations or delay their careers. Thus, they develop 'tied careers' with respect to their male partners' progression (Mincer 1978; Ackers 2004, 2005). These arguments underline serious problems that women have to face in their international work assignments, although, at the same time, they undervalue women's agency in managing their lives and professional careers.

Conversely, international mobility could be considered an opportunity for women in developing successful careers. In the first place, women with high educational qualifications are able to compete in the international labour market, and can thus escape the rigidities of the domestic labour market, particularly where gender issues are concerned (Kofman 1999, 2000). With regards to their partners' strategies, some research has shown that contemporary relationships are relatively equal, especially in the S\&T sector, where it is quite common to find both partners sharing similar personal and professional expectations (Hertz 1986; Monosson 2008). Thus, on the one hand, the partner who drives the mobility process is the partner with the strongest career aspirations and greatest opportunities in the global labour market (Green 1997; Favell 2008; Ho 2009). On the other hand, the partner who follows can take advantage of international mobility as well. In this way, both partners can be beneficiaries of a mobility strategy, securing additional training or credentials which will later support their own careers (Hardill 2004; Mullings 2005; Raghuram 2008). This suggests that the strategies of 
Table 1. Characteristics of women interviewed when they moved abroad (the most relevant international movement).

\begin{tabular}{|c|c|c|c|c|c|c|}
\hline Birth country & Occupation & Sector & Field & Stage & Partner & Children \\
\hline Argentinean & Computer Sciences & University & Scientific & Senior & Yes & No \\
\hline Brazilian & IT Project Manager & University & Engineering & Senior & Yes & No \\
\hline Colombian & IT Researcher & Research institution & Engineering & Junior & Yes & No \\
\hline Cuban & Technician Eng. & Enterprise & Engineering & Junior & Yes & No \\
\hline Czechoslovakian & IT Researcher & Research institution & Scientific & Junior & No & No \\
\hline Mexican & Technician Genetic & University & Scientific & Senior & Yes & 2 \\
\hline Peruvian & IT Designer & Enterprise & Engineering & Senior & No & No \\
\hline Russian & Physic Research & University & Scientific & Senior & Yes & 2 \\
\hline Serbian & IT Researcher & Research institution & Scientific & Junior & No & No \\
\hline Spanish & Math. Researcher & University & Scientific & Senior & Yes & 1 \\
\hline Spanish & IT Professional & Enterprise & Engineering & Junior & Yes & No \\
\hline Spanish & IT Researcher & University & Scientific & Senior & Yes & No \\
\hline Spanish & IT Designer & Enterprise & Engineering & Junior & No & No \\
\hline Spanish & Math. Researcher & University & Scientific & Senior & Yes & No \\
\hline Spanish & Social Researcher & University & Scientific & Junior & Yes & No \\
\hline Spanish & Social Researcher & University & Scientific & Senior & Yes & 2 \\
\hline Spanish & Genetic Researcher & Research institution & Scientific & Senior & Yes & No \\
\hline Spanish & IT Developer & Enterprise & Engineering & Senior & Yes & No \\
\hline Spanish & Math. Research & University & Scientific & Senior & No & No \\
\hline Spanish & IT Researcher & University & Scientific & Senior & Yes & No \\
\hline Spanish & Social Researcher & University & Scientific & Junior & No & No \\
\hline Spanish & IT Professional & Enterprise & Engineering & Senior & Yes & 2 \\
\hline Spanish & Social Researcher & Research institution & Scientific & Senior & Yes & No \\
\hline Spanish & IT Researcher & University & Scientific & Senior & Yes & No \\
\hline
\end{tabular}


women depend on labour market conditions, the age of their partners, the professional orientation of the couple and other dimensions of the partnerships and work-life balance, although there is still little empirical evidence regarding those topics.

A second dimension of analysis focuses on the particular problems that women have to face in developing their professional and personal lives abroad. Saltford (2005) emphasises the major constraints for women of balancing work and family responsibilities when they are living in a foreign country. She emphasises the lack of accessible and affordable childcare, and the difficulties of managing family responsibilities without informal support networks such as grandmothers and other relatives. Consequently, these women need to plan their work- life balance carefully, taking into account the fact that they have weaker and fewer support networks and that the provision of social services is done differently than in their home countries.

With vertical segregation in organisations, international mobility in the S\&T sector can be an additional obstacle to women's career progression. Promotion should be based on a fair and objective assessment of each candidate. However, this assessment can be gender-blind when it ignores the particular circumstances of women, since for them, international mobility constitutes an additional requirement for advancement (Ackers 2008). Research has shown the contradiction between the individual system of merit and the patriarchal organisation of the S\&T institutions (Hantrais, 1993), where men are easily rewarded while women are systematically ignored (Reskin 1979; Rossiter 1993; Evetts 1996; Krefting 2003; Addis 2004). Obstacles in women's careers make their professional trajectories cyclical and interrupted, while in linear careers it is easier to climb the professional ladder (Bagilhole and Goode 2001; Lyon and Woodward 2004).

\section{Methodology}

The findings discussed in the following sections are based on a broader research project on the mobility strategies of highly skilled personnel working in the S\&T sector. Approximately 50 men and women were interviewed to explore the effects of mobility on their professional careers and their life-courses. Nearly half of the women interviewed were in couples who spent some time abroad at the same time; this provided information from both partners. In the interviews we examined their personal and professional environments, the impact of country mobility on their careers, and the effects on their lives regarding partners, children and families. Although this article focuses solely on the experiences of women and on their discourses, we refer to their strategies as couples and comment on the diverse arguments used by women compared to those of their male counterparts.

For the purposes of this article, we analyse 24 in-depth interviews of highly skilled women working in the Spanish S\&T sector (see Table 1 for detailed information about their profiles while they were abroad). A key aim of this article is to explore how women adjusted their professional trajectories and personal decisions according to the demands of international careers, and how they conducted their lives abroad. The women we interviewed were found through a combination of non-random sampling (convenience, judgmental and snowball). They were selected according to characteristics that previous research has identified as relevant when analysing international mobility and gender (Hardill 2004; Ackers 2005; Saltford 2005; Kley and Mulder 2010; Xie 2010; González Ramos and Vergés 2011), such as nationality (country of birth); work (occupation, sector and stage); and family circumstances (marital status and dependants). Before discussing the analysis of the mobility strategies of the women we interviewed, we briefly introduce them in relation to these characteristics. 
In recent decades, the Spanish S\&T system has become more competitive in terms of results and attracting human resources, transforming the previous brain drain tendency into a brain circulation scheme (González Ramos 2011). This brain circulation involves more frequent flows of Spanish people moving abroad and foreigners coming to Spain, from Latin America and Eastern Europe (Pérez Sedeño 2005; Sanromá, Ramos, and Simón 2009). In accordance with this tendency, over two-thirds of the interviewees were Spanish women with the remainder coming from other countries. They planned their international mobility deliberately to develop learning and training opportunities, although a small proportion of these women were sent abroad by companies for which they were already working. In consequence, they spent long (more than one year) or short (only several months) periods of time abroad, and these were determined by their own choices or by the institutional requirements of their professional fields. Furthermore, all of them had occasional and very short periods abroad attending conferences, international meetings and travel on business; this is also discussed in the article.

The women interviewed were scientists and engineers working in S\&T-related activities (OECD 1994), thus they were highly skilled people. Most of them held positions in public institutions such as universities and centres of research; however, a quarter worked in private companies. The large concentration of women in the public sector is consistent with the statistical data for the whole of the European Union (European Commission 2009). Women in enterprises provided information about their different professional commitments and, above all, regarding the institutional support they received while on international assignments. Additionally, because these women had cyclical and interrupted careers, some of them worked in both public and private sectors, which was a conscious strategy for juggling their professional and personal goals. Therefore, we are able to make some comparisons between public and private sectors.

Women included in this study were at different stages of their professional S\&T careers with the prevailing two levels of expertise and responsibility corresponding to junior and senior phases. The literature suggests that the decision to move is mainly driven by life-course events and perceived opportunities in several life domains particularly linked to key transitions from school to tertiary education, union formation (marriage or cohabitation), separation and divorce situations, and the birth of children (Kley and Mulder 2010). Additionally, their age ranges allow us to make comparisons between junior and senior women, and to address some generational differences in mobility patterns as a result of the recent growth in international flows of human resources.

The marital status of the participants at the moment of the interview is relevant because it provides information about partners' influences on international mobility (Ackers 2004, 2005, 2008; Kley and Mulder 2010; Xie 2010). Although some of them were married, we treat all their relationships as formal unions when the women we interviewed described their partnerships in such a way. Of the women interviewed 18 had partners at the point when they decided to go abroad; 11 of these were in dual-career couples. It is interesting to note that at least two of the women interviewed got divorced as a consequence of their international mobility.

Motherhood has also been cited as an obstacle to professional career progression (Adler 1984; Xie and Shauman 2003; Ackers 2004, 2008; Fox 2005; Saltford 2005; Monosson 2008). Only six of the women we interviewed had children when they went abroad or during their work abroad, and three more women had children afterwards. Although some of the women we interviewed are young, some are old enough to have children. Those women explained childlessness as a consequence of their delayed maternity or complete rejection of motherhood. Otherwise, mothers described their 
experiences abroad with their small children, from babies to 11 years old, providing information about the social resources, the management of their time and the effects on their professional careers.

\section{Carefully planning their lives}

Women interviewed in this study explained that their main reason for going abroad was to learn and train for the advancement of their professional careers. However, there are significant nuances among women of different origins in their motivations for leaving their home country. While Spanish women seem more motivated by academic and professional factors, those from outside Spain cite personal reasons regarding the improvement of their family lives. These differences are also reflected in their mobility strategies: most Spanish women tend to go abroad for a limited period of time and return afterwards, while most women from outside Spain extend their stay abroad. Academic and professional factors shaped their mobility strategies at key transition moments: when they were in the last stages of their degree courses, tertiary courses, post-doctoral research periods, and when they were settling in new business centres in different countries. Personal reasons appeared linked to difficulties in the domestic labour market and the conditions of family life. The following quotation is from a Russian woman who gave a mixture of reasons for moving: difficulties in earning sufficient salary, problems in progress in her professional career and the need to improve her family life:

Children were small at that time, when I left. My daughter was six years old and my son was 11. But we decided to leave because it was a difficult time and a lot of people left. I worked in academia and also in a private school to obtain money to eat because our salaries were very low. There was not much money for research and I couldn't develop my professional career. So, my choice was to leave the country because, anyway, I couldn't see my children as I worked on Saturday and Sundays as well. So I did that and my family accepted my decision because I was trying to change something in our lives.

The women interviewed had positive assessments of their mobility experiences, highlighting both the professional and personal benefits. They emphasised the technical skills they acquired, as well as improved presence in international professional networks which contributed to their greater visibility and ability to compete in their professional careers. Most Latin American and Eastern European women had greater expectations of the personal and collective benefits they would derive from their mobile careers. So, they mentioned the well-being of their families and the provision of better educational opportunities for their children. In those cases, we found that their decisions were motivated as much by family strategies as simply by their own professional advancement.

Professional identities and ambitions lead women to formulate strategies of mobility in different ways, depending on their ages and expectations. Broadly speaking, younger and single women decide their future alone, but women in couples have to manage their decisions jointly with their partners (Green 1997; Ackers 2004; Hardill 2004; González Ramos and Vergés 2011). On the basis of the stories of their lives, we identified three types of situations.

Some of our women were the initiators of the decision to move, especially when they had strong career aspirations and a positive perception of the opportunities offered by the S\&T international labour market. This type of approach was exemplified by the Russian woman quoted above, as well as by two more women who moved abroad with their families, encouraged by their expectations of better job opportunities in the international labour market. 
However, the most common profile of the women we interviewed was that of women in dual-career households where their partners had similar interests, so they planned their professional and personal lives together. They decided their mobility strategies according to the timing of their careers and both partners supported each other. They also planned for successive periods of mobility in each professional career or planned for alternate periods abroad if they worked in different fields.

The first time we went to Cambridge because that time the choice was mine. The first time I chose it ... Then, the next was in Berkeley for a year. This time, it was his turn to choose, but I was delighted with his decision.

At least two of the interviewees followed their partners, but they described those periods as positive in their careers. One of them decided to enrol on a training course, and the second (quoted below) remarked that she had the most positive work experience of her whole life during that period of mobility.

At that time Jordi got a scholarship and he was going to London. And, I said: I am going with you, what am I going to do here alone? I looked for a job there and found it, and I was working there for a year. I was so happy there that I didn't want to come back, but of course the grant was running out and we had to come back.

In general terms, the women interviewed evaluated their decision to move as positive, even when they encountered obstacles and experienced some negative professional or personal consequences associated with moving. They emphasised the difficulties they had in returning to their previous situations, and uncertainty about the effects of moving on their career prospects in the domestic labour market. The following quote from a teacher in a Spanish university explains the problem (she uses 'he' universally although she was referring to both male and female professionals).

I think that the people that do their thesis abroad uh ... are very well considered. So, I mean, people say: 'Oh, if he has been at this university that is very prestigious ... Sure, he is very good I can learn a lot of him ... ' But, then, the ones that did their thesis abroad ... I don't think they find it so easy to return, to return to the ... market, especially, in Spain, because it is a bit ... Well, at the end, it seems that if you've been in a place for 6 years, it seems you have settled there, right?

The women we interviewed also emphasised some personal problems that they encountered in their mobility planning for the long term: family issues, social prejudices and relationship difficulties. Although some men showed a certain concern for personal and family issues, for example, initiating a return from abroad to be closer to their elderly parents, usually, women appeared to be more worried about the family. For example, two interviewees had to interrupt their careers to look after sick members of their families. These women also took more time and effort to explain their reasons behind moving abroad, clarifying the circumstances involved in their decision to move and the consequences for the whole family. Compared to men, women seemed more concerned about how international mobility affected the other members of their families.

Women who are ambitious with respect to career advancement are often negatively stereotyped. An Argentinean woman told us that her decision to go abroad was harshly criticised by her mother-in-law. Likewise, a Spanish university teacher felt that women with dynamic careers had more difficulties in meeting a partner and often were negatively judged because of their strong career orientation.

I had a partner but right now, I have no partner anymore. It is true that I spend loads of hours at work and probably ... I think that if I am alone it is because of work. I mean, if you want to get promoted, you work 24 hours a day, and other things suffer in your life ... As a woman, 
I think that if you had a partner who was not at the same professional stage as you, he would feel inferior to you. The opposite it is not true. If a man is a dean and has a secretary for a spouse, it is acceptable. But, in the opposite scenario ... the man would feel bad ... The couple would separate. So, women have few chances of finding someone who understands them.

Three women faced physical separation from their partners and families because of legal issues and shortages in the international labour market. Thus, there are institutional impediments to couples following joint mobility strategies, and brain circulation schemes need to take this into account. Policies and programmes for promoting the movement of talent tend to consider highly skilled personnel on an individual basis, without taking into account the fact that partners and children are also involved in the move. The following quote illustrates the difficulties faced by a senior researcher who lived in a number of European countries alone or, sometimes, with one of her two children.

I mean, in the last 12 years, we have only lived together for two of those years. So, it has been

a hard life and the children have hardly ever had the opportunity to live with the whole family.

Mobility is also linked to divorce in women's lives. Kley and Mulder (2010) have pointed out divorce may be the reason for moving abroad but, on the other hand, our interviewees tended to divorce as a consequence of their international mobility. One woman told us that she divorced because her partner could not settle in the host country and was permanently unemployed, so he decided to return to his country of origin, leaving his family in Spain. Another Spanish woman clearly associated the divorce with her move to the USA.

As a consequence of all these stays [in the USA] and all of those periods apart, in the end, we divorced. I was a year away, and when I came back I was dying to leave again.

These experiences indicate the importance for mobile women of their partners in meeting their work and family aspirations. Broadly speaking, partners play a key role because the more supportive they are, the easier women's lives are. The strongest statement to this effect was made by two senior Spanish women who felt really grateful to their partners because they had helped to support their professional careers despite long-standing social constraints. These women told us that their marriages made it easier for them to move to the USA in the 1960s. The commitment of both partners was central to these women's ability to balance their professional and personal lives, and so to overcome institutional barriers and social prejudices.

When trying to reconcile international mobility with parenthood, women usually take into account both their personal circumstances and labour market opportunities. For example, family planning for them involves waiting until one member of the couple has a permanent job. Occasionally, this decision involves adjustments in women's careers, for example, one Spanish woman moved from a private company to the academy because she considered it a more woman-friendly environment in terms of working time and flexible working.

\section{Managing daily lives}

International mobility involves challenges in having a proper family life in a foreign country while also pursuing a successful career. Women's experiences abroad vary, depending on factors such as their socioeconomic position, the type of family they belong to, their couple commitments and their career orientation. This also varies depending on the previous lifestyles in the home and the facilities they have in the host countries. The management of their lives abroad turns on legal issues, public policies, support for mobile workers and institutional constraints. When mobility also involves families, it is 
important to consider what kinds of public services and childcare facilities exist in the host country, and what type of gender equality policies are pursued.

A major problem faced by professionals from non-OECD countries lies in the legal constraints to the free movement of partners and families (Benhabib and Resnik 2009). Although the women we interviewed enjoyed relatively smooth entry to Europe, because they were protected by visas for highly skilled S\&T personnel, some of them had problems bringing their partners and children with them and securing accommodation for them all. These problems are made easier if economic and social support is available to mobile employees and their families. Not all of our interviewees received initial support with moving abroad because they initiated their own moves. However, most of them received some financial support from their employing organisations, covering travel and housing expenses. Partners with dual careers might have a travel grant each, while sometimes one member of the partnership has to use their own money too. Few support programmes or institutions feel it necessary to give support to both partners and to provide accommodation support for other members of the family. Only one woman, who worked in a large enterprise and was assigned to open a new office in the USA, was able to access additional benefits for family accommodation.

Well, the first year, [the company] helps you to find a house, if your husband or your kids don't speak the language, it gets you a teacher, it tries to help you to get to know the area ...

Some writers have argued that having it all is costly for women (Hertz 1986, 27). One of the women we interviewed referred to the difficulties involving in having a promising career and a partner at the same time. Although both women and men can be affected by this dilemma, gender stereotypes affect women much more strongly. These can then discourage women from moving into scientific and engineering careers because they perceive their personal and professional aspirations to be in tension. The following quote illustrates this fear, experienced by a junior woman working in a Spanish university:

If you have children it is more difficult to go abroad. Whether your partner works or not can also determine a lot. If your partner does not work, then it is easier to leave home if you have kids ... If you have children, home, family, it is not worth leaving ...

However, among our interviewees, adult women who lived with their small children abroad seemed to have managed work and family successfully. The following quotes illustrate the arrangements of two different women (both Spanish but one of them from the private sector and the other from a public research centre), since it underlines the relevance of properly organising the family.

I went first, and what I did was to rent the house and furnish it. When everything was ready the nanny came with the child, this was in October, which allowed me to look for a school that was to begin in January, after Christmas, more or less. My husband moved in December because my husband also managed to get his job transferred to the USA. We gave each other six months and in those six months he had the possibility to move there with the same company he already worked for.

We have always been able to travel together since we started, we were in the same research group, we both got scholarships, well, or grants to go to the same place ... so no problem, and when our daughter was born, we took her abroad, she went to the nursery school or wherever, we found a baby sitter and well, all easy, but now we pay more than we should because with the girl dependent on us and getting no more research scholarships but, well, it is not complicated at all.

The first problem that women encounter abroad is the lack of informal support networks to look after their children. Although the women we interviewed valued the support of their families, especially their children's grandmothers, some interviewees also stressed they 
could not count on their relatives before, in the home country, because they were elderly or lived away from them. Thus, their access to childcare was no better or worse in one country than in the other; in fact, the most important factor in supporting their childcare was the flexible working time which operated in the S\&T sector.

The second problem faced by women who move abroad with their children concerns the range of resources and the cultural differences between countries. Families have to find those services which are most convenient for them, sometimes depending on the proximity and availability of facilities and services, as explained by this woman who lived in the USA:

It is hard to find someone who can help you. Here, we usually have housekeepers who do everything: clean, bring the children to school ... Not there. There, housework is divided up: someone takes care of the children but does not clean clothes or dishes. Someone cleans but doesn't look after the children. On top of that, it is more expensive than in Spain. And it is even worse to consider putting your children in nursery school because North Americans think that women have to quit their jobs when they become mothers.

The conflict between professional careers and parenthood for women working abroad can be addressed by gender policies and work- life balance schemes. The women we interviewed had been living away from their home countries for a considerable period, and so were able to compare solutions for achieving their own aspirations as professionals and mothers. The more professionally oriented the careers they enjoyed, the more time our interviewees wanted to spend working while their children were taken care of. Most of these women were not in favour of taking part-time jobs because they saw these as antithetical to professional advancement. Equally, inadequate childcare facilities and short school hours were viewed negatively by the women with children whom we interviewed. The following statement was made by a Spanish woman with children abroad who moved to Germany and France in two different mobility periods.

... Everywhere, women are worse off than here [Spain], I mean ... in my situation, I mean, not women in general ... In France children don't have classes on Wednesdays and women stay at home ... . Certainly they are very happy, but I think that if children stayed at school from 8 am to $5 \mathrm{pm}$, that would be the ideal. In Germany maternity leave is longer [than in Spain], up to two years ... It could be very good, but women ... are losing their contact with research because of these measures.

International mobility is a previous condition for building competitive professional careers, and it also brings about wider recognition of women's merits. These issues are often highlighted as key areas of deficiency in patriarchal organisations, causing major problems for women's progression (Rossiter 1993; Bagilhole and Goode 2001; Lyon and Woodward 2004; Laudel and Gäser 2008). Peers in these types of organisations often prejudge the readiness of women to develop their careers, and question their loyalty to their employing organisations. Gender stereotypes affect appraisals of women who are seen as delaying their careers, abandoning them or engaging half-heartedly with organisational goals. In these situations, motherhood is often used to explain women's lack of progression. However, women usually find ways of managing motherhood, their professional responsibilities and their international mobility, as the following quote by a senior woman shows:

I do homework with my son using technology, messenger, mails, everything ... at home and when I am not there.

One woman explained that motherhood was one of the most creative phases of her career which clearly was reflected in her rates of publication. Another woman argued that men 
never need to explain what they do during their leisure time or sick periods, while women have to justify their maternity leave. Although, as we will show, women's style of work and their organisation of workplaces seem to be major impediments to their progression in S\&T careers, only mobility and motherhood were directly mentioned by our interviewees. With regards to the organisation of work, women manage tasks differently than men.

The women we interviewed handle different aspects of their work by multitasking (for example, academic staff combine research with management and teaching tasks), alternating different stages and different functions throughout their careers. By contrast, men carry out each function in successive stages (i.e. starting with research activities, later moving to management roles), which represent a linear trajectory. Women also take their professional careers at varying paces when they have to handle family responsibilities. This could be interpreted as meaning that they accomplish little at these times, and have low commitment to the objectives of their employing organisations. Women are often undervalued by their employers because of their different strategies to achieve their professional objectives and because their careers do not follow the same, linear trajectories.

Frequent visits to international meetings and attendance at scientific events generally contribute to the advancement of S\&T careers. Our research shows that women and men are equally motivated to move abroad for their careers, despite the fact that women generally need more support and resources to do this because they are more likely to take prime responsibility for family and children. Changes in social values, positive action in institutions and gender policies can help women to manage these various demands on a daily basis. For, unless they have very supportive partners, women usually have to manage most family responsibilities on their own. If we want to promote female talent in the S\&T sector, a wide range of measures are needed to facilitate their progression, particularly measures to support the internationalisation of their careers.

\section{Final remarks on women's international careers}

International mobility seems to be a widespread phenomenon resulting from the growth and dynamism of knowledge economies, where women from less developed economies and high levels of qualification move to other countries more than men do. Our research found that women had professional as well as personal reasons for wanting to move abroad. International mobility can thus offer an opportunity for women in S\&T to overcome career obstacles in their home countries which are related to gender discrimination and disadvantage. We also found that women's decisions to transfer abroad were usually associated with family considerations and not only with their personal motivations.

As a result of their growing professional ambitions, women actively develop mobility strategies, even when these involve the displacement of partners and children. Among the women we interviewed, they either initiated the decision to move, shared the decision with their partners, or followed their partners, but they still had their own plans for developing their careers abroad. Consequently, the women in this research were very satisfied with their international experiences because these contributed to their professional advancement and had positive effects on their lives.

The development of international careers requires the commitment of partners and family. In this regard, the selection of partners appears to be a very important issue and the women who participated in this study sought supportive partners. Even so, they needed determination and a great deal of organisation to pursue their professional objectives as 
well as their personal ones. In the process of doing so, other obstacles and issues confronted them during their lives, often caused by stereotyping and discrimination.

Organisational progression criteria tend to define linear careers as the norm, and they are therefore better rewarded. Because women generally have to manage their work and their family responsibilities, they are more likely to have cyclical and interrupted careers. Some women managed their careers by delaying motherhood, planning their international mobility carefully and in consultation with their families, and by taking advantage of all the resources made available by governments and institutions. The decisions that women and men made about their own careers were based on different criteria, because women had to plan their time carefully on a long-term basis as well as on a daily basis.

Some of the difficulties which women had to face in their mobile working lives appeared to be consequences of mobility schemes that were narrowly conceived and treated mobile employees as lone individuals, without taking into account the whole lives of these highly skilled staff. There were legal restrictions on the mobility of partners and children, and little support for families in finding accommodation abroad. New patterns of living and family arrangements are emerging among skilled people that governments and institutions should take into account in their policy-making for knowledge society. Only in this way will female talent be attracted into the S\&T sector.

Organisations in the S\&T sector are aware of the need for female participation in the production and transfer of knowledge, yet women still have to address the obstacles to their participation largely on their own. Thus, more active S\&T mobility policies should facilitate work- life balance and promote progression based on women's own career patterns. This means that organisational and cultural changes are needed to promote friendlier environments for women working away from home so that they can form a diverse workforce which can be turned to real advantage.

Social values already restrict women to family roles, while professions and employment are still considered masculine domains. Thus, women with strong career aspirations not only have to deal with problems related to the management of their lives (for example, the management of their time and of their family roles), but they also have to struggle with social stereotypes and prejudices (for example, from family members and those who seek to undermine their work and their commitment to their families). As a result, women have severe conflicts between their personal and professional lives which they try to reconcile through supportive partnerships, carefully planned long-term strategies and detailed planning of their daily lives.

Although women's progression in professional S\&T areas involves numerous difficulties, some of them can be overcome by practical measures which might include:

- more comprehensive mobility polices related to family reunification and accommodation;

- more varied, accessible and affordable social services for people on international assignments such as nursery schools, language courses and support for partners in their job searches; and

more flexible performance assessment criteria based on the recognition of different career strategies and trajectories, both linear and otherwise.

Heavy demands on women at work and in the home create multiple tensions in their lives and in the labour market more generally. The fact that those tensions tend to be resolved by women and their families on an individualised basis rather than collectively within society suggests that these tensions are not sufficiently socially visible. This invisibility, in turn, 
serves to reinforce social assumptions that masculine career trajectories are the norm. These facts act as a barrier to girls who are less interested in S\&T careers and to the progression of women who tend to remain in lower positions.

\section{Acknowledgements}

This article forms part of a research project funded by the Ministry of Science and Innovation (CSO2009-09003). We would like to thank all women interviewed, because their words are the basis of this work. We also appreciate the comments and helpful support of Juliet Webster, Paul Scott, Sara Campbell and Kristin Hickey.

\section{References}

Ackers, L. 2004. Managing work and family life in peripatetic careers: The experiences of mobile women scientists in the European Union. Women's Studies International Forum 27, no. 3: $189-201$.

- 2005. Moving people and knowledge: Scientific mobility in the European Union. International Migration 43, no. 5: 99 - 131.

. 2008. Internationalisation, mobility and metrics: A new form of indirect discrimination? Minerva 46: $411-35$.

Addis, E. 2004. Gender in the publication process: Evidence, explanations, and excellence. In Gender and Excellence in the making. Brussels: European Commission, Directorate General for Research Information and Communication Unit.

Adler, N.J. 1984. Women do not want international careers: And other myths about international management. Organizational Dynamics 13: $66-79$.

Bagilhole, B., and J. Goode. 2001. The contradiction of the myth of individual merit, and the reality of a patriarchal support system in academic careers: A feminist investigation. European Journal of Women's Studies 8, no. 2: $161-80$.

Benhabib, S., and J. Resnik. 2009. Migrations and mobilities: Citizenship, borders, and gender. New York: New York University Press.

Castells, M. 1996. The information age: Society and culture. Cambridge, MA: Blackwell.

Docquier, F., L.B. Lowell, and A. Marfouk. 2009. A gendered assessment of the brain drain emigration. Population and Development Review 35, no. 2: 297 - 321.

Dumont, J.C., J.P. Martin, and G. Spielvogel. 2007. Women on the move: The neglected gender dimension of the brain drain. IZA Discussion Paper No. 2920, Bonn.

European Commission. 2009. She figures 2009: Statistics and indicators on gender equality in science. Brussels: Directorate General for Research Information and Communication Unit.

Evetts, J. 1996. Gender and career in science and engineering. Bristol: Taylor and Francis.

Favell, A. 2008. Eurostars and Eurocities: Free movement and mobility in an integrating Europe. Oxford: Blackwell.

Fox, M.F. 2005. Gender, family characteristics, and publication productivity among scientists. Social Studies of Science 35, no. 1: $131-50$.

González Ramos, A.M. 2011. Atrayendo talento: Estrategias de movilidad de los profesionales altamente Cualificados en España. Sociología y Tecnociencia 1, no. 2: 72-87.

González Ramos, A.M., and N. Vergés. 2011. Moving for what? International mobility strategies of women in ICT careers. International Journal of Gender, Science and Technology 3, no. 2: $501-16$.

Green, A.E. 1997. A question of compromise? Case study evidence on the location and mobility strategies of dual career households. Regional Studies 31, no. 7: 641 - 57.

Hanson, S. 2010. Gender and mobility: New approaches for informing sustainability. Gender, Place and Culture 17, no. 1:5-23.

Hantrais, L. 1993. The gender of time in professional occupations. Time and Society 2, no. 2: 139-57.

Hardill, I. 2004. Transnational living and moving experiences: Intensified mobility and dual-career households. Population, Space and Place 10, no. 5: 375 - 89.

Hertz, R. 1986. More equal than others: Women and men in dual-career marriages. Berkeley: University of California Press.

Ho, E.L. 2009. Migration trajectories of 'highly skilled' middling transnationals: Singaporean transmigrants in London. Population, Space and Place, doi: 10.1002/psp.569.

Jöns, J. 2007. Transnational mobility and the spaces of knowledge production: A comparison of global patterns, motivations and collaborations in different academic fields. Social Geography 2: 97-114. 
King, R., and E. Ruiz-Gelices. 2003. International student migration and the European 'year abroad': Effects on the European identity and subsequent migration behaviour. International Journal of Population Geography 9: 229 -52.

Kley, S., and C.H. Mulder. 2010. Considering, planning, and realizing migration in early adulthood: The influence of life-course events and perceived opportunities on leaving the city in Germany. Journal of Housing and the Built Environment 25: 73 - 94.

Kofman, E. 1999. Female 'birds of passage' a decade later: Gender and immigration in the European Union. International Migration Review 33, no. 2: 269 - 99.

- 2000. The invisibility of skilled female migrants and gender relations in studies of skilled migration in Europe. International Journal of Population Geography 6: 45 - 59.

Koser, K., and J. Salt. 1997. The geography of highly skilled international migration. International Journal of Population Geography 3, no. 4: 285 - 303.

Krefting, L.A. 2003. Intertwined discourses of merit and gender: Evidence from academic employment in the USA. Gender, Work and Organization 10, no. 2: 260 - 78.

Laudel, G. 2005. Migration currents among the scientific elite. Minerva 43: 377 - 95.

Laudel, G., and J. Gläser. 2008. From apprentice to colleague: The metamorphosis of early career research, higher education. The International Journal of Higher Education Planning 55, no. 3: $387-406$.

Lyon, D., and A.E. Woodward. 2004. Gender and time at the top: Cultural construction of time in high-level careers and homes. European Journal of Women's Studies 11, no. 2: 205 - 21.

Mahroum, S. 2000. Highly skilled globetrotters: Mapping the international migration of human capital. $R \& D$ Management 30, no. 1: $23-31$.

. 2001. Europe and the immigration of highly skilled labor. International Migration 39, no. 5: $27-43$.

Mincer, J. 1978. Family migration decision. Journal of Political Economy 86: 749 - 73.

Monosson, E., ed. 2008. Motherhood, the elephant in the laboratory: Women scientists speak out. New York: Cornell University Press.

Mullings, B. 2005. Women rule? Globalization and the feminization of managerial and professional workspaces in the Caribbean. Gender, Place and Culture 12, no. 1: 1 - 27.

OECD. 1994. Manual on the measurement of human resources devoted to S\&T-Canberra Manual. Paris: OECD.

2001. Innovative people: Mobility of skilled personnel in national innovation systems. France: OECD.

2007. International migration outlook: Annual report 2007 edition. OECD: Paris. 2008. A profile of immigrant populations in the 21 st century. Data from OECD Countries, OECD.

Pérez Sedeño, E. 2005. Los Programas de Formación y Movilidad del Personal Investigador de Flujo Directo e Inverso: Problemas, retos y soluciones. http://82.223.160.188/mec/estudios _analisis/proyectos2005/EA2005-0004.pdf (accessed August 6, 2010).

Raghuram, P. 2008. Migrant women in male-dominated sectors of the labor market: A research agenda. Population, Space and Place 14: 43 - 57.

Reskin, B. 1979. Academic sponsorship and scientists' careers. Sociology of Education 52: 129-46.

Rossiter, M.W. 1993. The Matthew Matilda effect in science. Social Studies of Science 23, no. 2: $325-41$.

Saltford, H. 2005. Parenting, care and mobility in the EU: Issues facing migrant scientists. Innovation 18, no. 3: $361-80$.

Sanromá, E., R. Ramos, and H. Simón. 2009. Immigrant wages in the Spanish labour market: Does the origin of human capital matter?. IZA DP No. 4157.

Solimano, A. 2008. The international mobility of talent: Types, causes and development impact. Oxford: Oxford University Press/UNU-WIDER Studies in Development Economics Research.

Xie, Y. 2010. Gender asymmetry in family migration: Occupational inequality or interspousal comparative advantage? Journal of Marriage and Family 72: 375 - 92.

Xie, Y., and K.A. Shauman. 2003. Women in science: Career processes and outcomes. Cambridge, MA: Harvard University Press. 